\title{
Heart transplantation with generic immunosuppression - a developing country experience
}

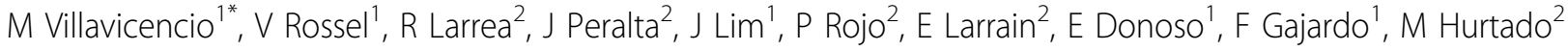 \\ From 23rd World Congress of the World Society of Cardio-Thoracic Surgeons \\ Split, Croatia. 12-15 September 2013
}

\section{Background}

Heart transplantation is the therapy of choice for advance heart failure. Our group developed two transplant programs at Instituto Nacional del Torax and Clinica Davila. We report our clinical experience based with generic immunosuppression with may have lower costs and may allow more patients to be transplanted.

\section{Methods}

Fifty-three consecutive patients were transplanted between November 2008 and April 2013, representing $51 \%$ of all Chilean cases.

\section{Results}

Ischemic or dilated cardiomyopathy were the main indications (23(43\%) each), age $48+13$ years and $48(91 \%)$ were male. Transplant listing Status: IA 14(26\%)(VAD or 2 inotropes), IB 14(26\%)(1 inotrope) and II 25 (47\%) (no inotrope). Mean waiting time $70+83$ days. Twelve (24\%) were transplanted during VAD support (median support: 36 days). Operative technique: orthotopic bicaval transplant with ischemia time: $175+54 \mathrm{~min}$. Operative mortality: 3 (6\%), all due to right ventricular failure. Re-exploration for bleeding $2(4 \%)$, stroke 3(6\%), mediastinitis $0(0 \%)$, pneumonia $4(8 \%)$, and transient dialysis 6 (11\%). Mean follow-up was $21+14$ months. Three-year survival was $86+6 \%$. One patient died of Pneumocystis Jirovecii pneumonia and the other died suddenly (noncompliance). Freedom from rejection requiring specific therapy was $80+7 \%$ at 3 years of follow-up. Four hundred eighty four endomyocardial biopsies were done: 11(2.3\%) had $2 \mathrm{R}$ rejection. All survivors are in NYHA (New York

\footnotetext{
* Correspondence: villavicencio.mauricio@gmail.com

${ }^{1}$ Cardiopulmonary Transplant, Instituto Nacional del Torax, Santiago, Chile

Full list of author information is available at the end of the article
}

Heart Association) functional class I and all but one has normal biventricular function.

\section{Conclusion}

Mid-term results are similar to those reported by the registry of the International Society for Heart and Lung Transplantation. Rejection rates are low in spite of generic immunosuppression.

\section{Authors' details}

${ }^{1}$ Cardiopulmonary Transplant, Instituto Nacional del Torax, Santiago, Chile.

${ }^{2}$ Cardiopulmonary Transplant Unit, Clinica Davila, Santiago, Chile.

Published: 11 September 2013

doi:10.1186/1749-8090-8-S1-0157

Cite this article as: Villavicencio et al.: Heart transplantation with generic

immunosuppression - a developing country experience. Journal of

Cardiothoracic Surgery 2013 8(Suppl 1):0157.

Submit your next manuscript to BioMed Central and take full advantage of:

- Convenient online submission

- Thorough peer review

- No space constraints or color figure charges

- Immediate publication on acceptance

- Inclusion in PubMed, CAS, Scopus and Google Scholar

- Research which is freely available for redistribution

Submit your manuscript at www.biomedcentral.com/submit

\section{() Biomed Central}

